\title{
Antibacterial activity of partially purified enterocins from foodborne and clinical enterococci against some pathogenic bacteria
}

\author{
Zerrin ERGINKAYA ${ }^{1, a}$, Hatice ULUDAĞ ${ }^{1, b}$, Emel ÜNAL TURHAN ${ }^{2, c, ®}$ \\ ${ }^{1}$ University of Çukurova, Faculty of Agriculture, Department of Food Engineering, Adana; ${ }^{2}$ University of Osmaniye Korkut Ata, \\ Kadirli Applied Sciences School, Department of Food Technology, Osmaniye, Turkey. \\ aORCID: 0000-0001-6208-2927; ' ${ }^{\mathrm{a}}$ ORCID: 0000-0003-2085-8556; ' ORCID: 0000-0002-0284-574X.
}

${ }^{凶}$ Corresponding author: emelunalturhan@ gmail.com

Received date: 22.03.2019- Accepted date: 26.06 .2019

\begin{abstract}
The purpose of the present research was to obtain enterocins from bacteriocinogenic enterococci (Enterococcus faecalis and Enterococcus faecium) in clinical and food sources, and to determine antibacterial activity of these enterocins against pathogenic bacteria including Escherichia coli, Staphylococcus aureus, Bacillus cereus and Salmonella Enteritidis. Enterocins were partially purified with ammonium sulfate precipitation from E. faecium and E. faecalis. After purification, the antimicrobial activity of enterocin was tested on Mueller Hinton Agar by disk diffusion assay. The 13, 8, 4 and 1 of 20 bacteriocins obtained by Enterococcus strain showed antimicrobial effect against $S$. Enteritidis, B. cereus, E. coli and S. aureus, respectively. One of food origin Enterococcus (E. faecium) exhibited the antimicrobial effect on all of the pathogen microorganisms used in our study. Enterocins from food and clinical isolates were very effective against Salmonella Enteritidis. The most active enterocins were produced by enterococci isolates from Hatay cow cheese due to their antibacterial spectrum on pathogenic bacteria used in this study. This study concluded the importance of investigating clinical enterococci besides foodborne enterococci to benefit from antibacterial properties.
\end{abstract}

Keywords: Antibacterial, bacteriocin, enterococci, enterocin.

\section{Gıda ve klinik kaynaklı enterokoklardan kısmi saflaştırılmış enterosinlerin bazı patojen bakterilere karşı antibakteriyel aktivitesi}

Özet: Bu çalışmanın amacı klinik ve gıda kaynaklı bakteriyosin aktif enterokoklardan (Enterococcus faecalis ve Enterococcus faecium) enterosin elde etmek ve bu enterosinlerin Escherichia coli, Staphylococcus aureus, Bacillus cereus and Salmonella Enteritidis gibi patojen bakterilere karşı antibakteriyel aktivitesini belirlemektir. Enterosinler, E. faecium ve E. faecalis'ten amonyum sülfat çökeltmesi ile kısmen saflaştırılmıştır. Saflaştırmadan sonra, enterosinlerin antimikrobiyel aktivitesi disk difüzyon yöntemine göre Mueller Hinton Agar üzerinde test edilmiştir. Enterokok suşları tarafindan elde edilen 20 bakteriyosinin 13'ü, 8'i 4'ü ve 1'i sırasıyla, $S$. Enteritidis'e, B. cereus'a, E. coli'ye ve $S$. aureus'a karş1 antimikrobiyel etki göstermiştir. Gıda kaynaklı enterokokların biri ( $E$. faecium) çalışmamızda kullanılan patojen mikroorganizmaların hepsi üzerinde antimikrobiyel etki göstermiştir. Gıda ve klinik kaynaklı enterosinler Salmonella Enteritidis'e karşı oldukça etkili bulunmuştur. En aktif enterosinler, bu çalışmada kullanılan patojenik bakteriler üzerindeki antibakteriyel spektrumları nedeniyle Hatay inek peynirinden elde edilen enterokok izolatları tarafindan üretilmiştir. $\mathrm{Bu}$ çalışma antibakteriyel özelliklerden yararlanmak için gıda kaynaklı enterokokların yanı sıra klinik kaynaklı enterokokların araştırılmasının önemini göstermiştir.

Anahtar sözcükler: Antibakteriyel, bakteriyosin, enterokok, enterosin.

\section{Introduction}

Nowadays, there is an increased interest to apply and investigate natural additives including antimicrobials and antioxidants in food and feed. Consumers prefer food products of high quality, prepared without artificial preservatives, safe and with long shelf-life. For this reason, researchers focused on bacteriocins known as microbial metabolites $(18,21,30)$. Bacteriocins or bacteriocinogenic cultures seen as useful biocontrol agents in food preservation to ensure the microbial safety and decrease the risk of the growth of spoilage or pathogenic microorganisms such as Staphylococcus aureus, Listeria monocytogenes, Escherichia coli, Pseudomonas spp., Bacillus spp., Salmonella spp., and Clostridium spp. (12, 17, 18).

The bacteriocins are small, cationic, amphiphilic, antimicrobial peptides which ribosomally synthesized by mostly lactic acid bacteria (16). Enterococcus spp. are 
resistant to harsh or extreme conditions, such as high and low temperatures, extreme $\mathrm{pH}$ and salinity. These properties make it possible for bacteria and their bacteriocins to be used in any food products (6). Due to bacteriocinogenic activity of enterococci against foodborne pathogenic and spoilage bacteria, various researchers focused on novel enterocins (1). Bacteriocinogenic enterococci strains, mostly E. faecalis and E. faecium, were isolated from different sources including vegetables, fermented foods (cheese, sausages and other meat products), gastrointestinal system and various clinical specimens like urine, skin swab, pus, and blood $(3,6,7,18,25)$.

In the previous studies, a majority of bacteriocinproducing enterococci have been obtained from food such as cheese, meat, fish, and vegetables $(4,17)$. While most of the papers on enterocins has related to bacteriocinogenic enterococci from food sources, less attention has been given to isolates from the clinical origins. As a matter of fact, studies concerning the use of enterocins from clinical origin are scarce compared with food sources. The isolation of novel bacteriocins will be beneficial for food and other related industries $(15,18)$.

The present study aimed partially purification of enterocins from bacteriocinogenic enterococci (E. faecalis and E. faecium) from clinical and food sources, and to investigate inhibition effect of these enterocins against $E$. coli, S. aureus, B. cereus, and S. Enteritidis.

\section{Material and Methods}

Samples and bacterial strains: A total of 20 enterococcal isolates (10 of E. faecium and 10 of $E$. faecalis) from several sources (10 from clinical cases and 10 from foods) were collected from a stock culture in Food Microbiology Laboratory, Food Engineering Department, University of Çukurova. Isolates in stock were previously obtained from cheese, kasseri, sucuk, chicken meat (5 of E. faecium and 5 of E. faecalis) and stool or rectal specimens (5 of E. faecium and 5 of E. faecalis). Enterococci were grown in De Man, Rogosa and Sharpe broth (MRS broth; Merck, Darmstadt, Germany). Pathogenic bacteria including Escherichia coli O157:H7 ATCC-35150, Bacillus cereus isolate, Salmonella Enteritidis isolate and Staphylococcus aureus ATCC25923 were used as indicator organisms. Pathogen bacteria were grown in Brain heart infusion (BHI) broth (Merck KGaA, Darmstadt-Germany) and stocked at $-20^{\circ} \mathrm{C}$ in BHI supplemented with $20 \%$ (v/v) glycerol (18).

Partially purification of enterocins from enterococcal isolates: Enterocins were partially purified from food and clinically isolates of E. faecium and $E$. faecalis according to modified method of Anandani and Khan (2); Savadago et al. (21); Javed et al. (13). The enterococcal isolates were incubated for $48 \mathrm{~h}$ at $37^{\circ} \mathrm{C}$, in flask including $250 \mathrm{~mL}$ MRS broth. After incubation, this mix was centrifuged $\left(10000 \mathrm{~g}\right.$ at $\left.4^{\circ} \mathrm{C}, 20 \mathrm{~min}\right)$ for separation of the cell-free culture supernatant (CFS). $10 \mathrm{~N}$ NaOH (Merck, CAS No.1310-73-2 pellets EMPLURA) to exclude the antimicrobial effect of organic acid was added to CFS with the adjustment of $\mathrm{pH}$ 6.5. Then, CFS was sterilized by using $0.45 \mu \mathrm{m}$ membrane filter (Millipore, Carrigtwohill, Ireland). Ammonium sulphate (Merck Millipore) was slowly added to this sterile CFS suspension to reach $40 \%$ saturation and this mixture was stirred overnight at $4^{\circ} \mathrm{C}$. The centrifugation of this mixture (13000 $\mathrm{g}$ at $4^{\circ} \mathrm{C}, 45 \mathrm{~min}$ ) ensured the harvesting of the surface pellicles and bottom pellets and thus, resuspension was performed in $10 \mathrm{~mL}$ of $10 \mathrm{mM}$ sodium phosphate buffer (Merck-pH 7). The extraction procedure was performed at $4^{\circ} \mathrm{C}$ for $1 \mathrm{~h}$ by adding 15 volumes of a methanol-chloroform (Sigma-Aldrich) mixture (1:2, v/v) to one volume of the resuspended product. After the centrifugation of sample $\left(15500 \mathrm{~g}, 4^{\circ} \mathrm{C}, 30 \mathrm{~min}\right)$, cell-free supernatant and pellet were separated. The pellet was resuspended in $10 \mathrm{~mL}$ of ultrapure water (MilliQ; Millipore N.V., Brussels, Belgium). This partially purified enterocin extract was defined as a bacteriocinogenic sample and stored at $+20^{\circ} \mathrm{C}$. The presence of enterocins in extracts or bacteriocinogenic samples obtained from these enterococci strains was detected by antimicrobial activity test. Extracts causing inhibitory activity were evaluated as bacteriocinogenic positive $(\mathrm{Bac}+)$ otherwise bacteriocinogenic negative (Bac-).

The determination of antimicrobial activity of enterocins from different sources: After purification, the antimicrobial activity of enterocin was tested on Mueller Hinton Agar (MHA, Oxoid-UK) by disk diffusion assay against Escherichia coli O157:H7 ATCC-35150, Bacillus cereus, Salmonella Enteritidis and Staphylococcus aureus ATCC-25923 as target (indicator) strains with a bit modification of previous reports $(14,21)$. Disk diffusion assay was used for detection of antimicrobial activity from enterocins of enterococcal strains. Pathogenic indicator

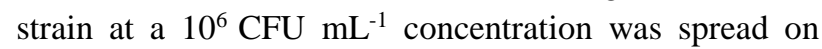
MHA and then paper disks were placed on these agar plates. Afterward, $100 \mu \mathrm{L}$ portions of bacteriocinogenic samples were placed on these paper disks (thick, $6 \mathrm{~mm}$, Oxoid-UK) and the plates were incubated at $37^{\circ} \mathrm{C}$, for 24 $\mathrm{h}$. The detection of antimicrobial activity was carried out with the measurement of translucent halos in the bacterial lawn surrounding the disks. Diameters of inhibition zone around the disks were measured in millimeters. The observation of the inhibition zone has supported the presence of enterocins in partially purified extract from enterococcal strains. 


\section{Results}

Antimicrobial activity of enterocins from foodborne enterococcal strains was represented in Table $1.40 \%$ of enterocins from $E$. faecium with food origin inhibited $B$. cereus and E. coli, whereas $60 \%$ and $20 \%$ of these had inhibition effect on $S$. Enteritidis and $S$. aureus, respectively. $60 \%$ of enterocins from foodborne $E$. faecalis showed antibacterial activity against B. cereus and $S$. Enteritidis, however, none of them had inhibition effect on E. coli and S. aureus.

Inhibitory activity of enterocins from clinical enterococci was shown in Table 2. $60 \%$ of enterocins from $E$. faecium with clinical sources inhibited $S$. Enteritidis and $20 \%$ of these exhibited inhibition effects on $B$. cereus and E. coli, whereas none of them had antibacterial activity against $S$. aureus. 80, 40 and $20 \%$ of enterocins from $E$. faecalis with clinical origin showed antibacterial activity against $S$. Enteritidis, B. cereus and $E$. coli, respectively, whereas none of them inhibited $S$. aureus.

As seen our results, enterocins from E. faecium in Hatay cow cheese showed antibacterial activity against studied all pathogenic bacteria. Enterocins from Erzincan
Tulum cheese, kangal sucuk and homemade cheese were found as "Bac -". Enterocins from clinical isolates V146 and 225 did not display bacteriocinogenic effect on indicator microorganisms. Enterocins from food and clinical isolates mostly had an inhibition effect on $B$. cereus and $S$. Enteritidis. One of the food isolates and none of the clinical isolates exhibited antibacterial activity against $S$. aureus.

\section{Discussion and Conclusion}

Bacteriocins were produced from different microorganisms such as Lactobacillus sp., Leuconostoc sp., Lactococcus sp., Pediococcus sp., Streptococcus sp., Enterococcus spp. and different origin such as food, clinical substances, and environmental etc. (23). E. faecalis and E. faecium are the main species of enterococci, the most commonly found both in food and in clinical samples (3). On this sense, E. faecalis and E. faecium were selected as bacteriocinogenic isolates because previous researchers mostly reported E. faecium and $E$. faecalis as bacteriocin producer strains $(5,7,16$, 19, 25, 28, 29).

Table 1. Inhibition zone diameter from foodborne enterocins against pathogens (mm).

\begin{tabular}{lcccccc}
\hline Code & Food samples & Source of enterocins & B. cereus & S. Enteritidis & E. coli & S. aureus \\
\hline L13 & Hatay cow cheese & E. faecium & 6.00 & 9.50 & 6.50 & 9.00 \\
P18 & Kasseri & E. faecium & - & 8.50 & 5.50 & - \\
H8 & Erzincan Tulum cheese & E. faecium & - & - & - & - \\
E5 & Antep cheese & E. faecium & 10.00 & 7.00 & - & - \\
YS1 & Kangal sucuk & E. faecium & - & - & - & - \\
JS1 & Chicken meat & E. faecalis & 7.00 & 10.00 & - & - \\
NS1 & Homemade sucuk & E. faecalis & - & 7.00 & - & - \\
A1 & Urfa cheese & E.faecalis & 13.00 & 12.00 & - & - \\
LS1 & Chicken meat & E. faecalis & 11.00 & - & - & - \\
AS1 & Homemade cheese & E. faecalis & - & - & - & - \\
\hline
\end{tabular}

Table 2. Inhibition zone diameter from clinical enterocins against pathogens (mm).

\begin{tabular}{lccccc}
\hline Code & Source of enterocins & B. cereus & S. Enteritidis & E. coli & S. aureus \\
\hline V150 & E. faecium & - & 9.00 & - & - \\
V105 & E. faecium & - & 12.00 & - & - \\
V98 & E. faecium & - & - & 8.00 & - \\
V146 & E. faecium & - & - & - & - \\
V198 & E. faecium & 7.00 & 9.00 & - & - \\
225 & E. faecalis & - & - & - & - \\
226 & E. faecalis & 10.00 & 14.00 & - & - \\
227 & E. faecalis & 8.00 & 9.00 & -00 & - \\
228 & E. faecalis & - & 11.00 & - & - \\
V188 & E. faecalis & - & 11.00 & - & - \\
\hline
\end{tabular}


In this study, diameters of inhibition zone caused by enterocins show their effectiveness of the antimicrobial activity. According to this, the presence and absence of antimicrobial activity of enterocins were evaluated as "Bac +" and "Bac -", respectively for the strains from which they were obtained. The present research clearly demonstrated the importance of enterocins from $E$. faecium and E. faecalis in both food and clinical sources with regard to their inhibitory activity against major foodborne pathogens including $E$. coli O157:H7, B. cereus, S. Enteritidis and $S$. aureus. Khalkhali and Mojgani (14) stated that enterocin-like substances produced by E. faecalis and E. faecium caused strong antibacterial activity (zone diameter $\geq 20 \mathrm{~mm}$ ) against $E$. coli, Salmonella typhi and S. aureus but caused weak (zone diameter $\leq 15 \mathrm{~mm}$ ) or no (absence of a zone of inhibition) antibacterial activity against $B$. cereus. Enterocins obtained from the present study have weak antibacterial activity. Similar to our data based on inhibition zone diameter, Savadago et al. (21) reported that bacteriocins produced by lactic acid bacteria gave zones of inhibition (between 9 and $10 \mathrm{~mm}$ ) onto B. cereus, E. coli, and $S$. aureus.

Nowadays, there is a trend to detect novel enterocins from different enterococcal sources (16). Especially, the importance of enterocins from E. faecium and E. faecalis was emphasized as regards antibacterial spectrum (12, 22, 26). For example, Javed et al. (12) isolated and identified E. faecium and E. faecalis as bacteriocin producing enterococcal strains from indigenous fermented dairy products of Pakistan. Similarly, the present study detected that some of E. faecium and E. faecalis strains were Bac (+). Isleroglu et al. (11) confirmed that several bacteriocinogenic enterococcal strains isolated from various food products exhibited an antibacterial effect on foodborne pathogens and food spoilage bacteria. Franz et al. (8) found that approximately $3 \%$ of lactic acid bacteria isolates were bacteriocinogenic activity against one or more of the indicator strains. Similarly, in our study, not all isolates had "Bac +", some of them were found as Bac (-). Both clinical and foodborne enterococci used in this paper may be candidate strains for practical use. However, there is a need for information in order to distinguish enterocins (16). Therefore, researchers should focus on the risk factors associated with virulence trait of bacteriocinogenic enterococcal strains and their technological properties. The presence of virulence traits in these enterococcal strains should be carefully monitored for safety parameters of their enterocins (14).

Previous researchers reported that majority of enterocins displayed antibacterial activity against Grampositive bacteria as well as few effective against Gramnegative bacteria $(1,9,20,26)$. Isleroglu et al. (11) reported that enterocins had little or no activity against
Bacillus and Staphylococcus, Salmonella and E. coli. Similarly, in our study, inhibitory effect of enterocin against $S$. aureus was found less than other strains. $S$. aureus is generally more resistant to enterocins because Staphylococcus possesses the ability to form a viscous or gelatinous polysaccharide capsule that prevents the penetration of antimicrobial compounds into the bacterial cells (17). On the other hand, the present paper concluded that enterocins showed inhibition effect against grampositive and negative bacteria. In accordance with our results, Sparo et al. (24), stated that enterocins from some enterococcal strains displayed the ability to inactivate the growth of both gram positive and negative bacteria. As a result, it was considered that the inhibition effect is strain specific. Bacteriocins have different antimicrobial spectra due to their different modes of action (27). The mode of antibacterial activity of bacteriocins depends on various factors such as the available concentration, characterizations of target or indicator strains and media. For example, antimicrobial resistance of target strains is the main factor related with the effectiveness of bacteriocins $(16,22)$.

The present study emphasized the importance of $E$. faecalis as a source of enterocin with broad antimicrobial spectrum similar to the work of Belguesmia et al. (5). The differentiation related to antimicrobial spectrum of enterocins may explain resistance mechanisms of microorganisms (5). Additionally, enterocin produced by E. faecium isolates from food had inhibition effect on all pathogenic bacteria used in this study. This situation considered that enterocin from E. faecium in food isolates may provide protection against pathogen. Additionally, enterocin from E. faecalis in clinical sources exhibited the highest antibacterial activity against $S$. Enteritidis. As seen our results, there is variability in antimicrobial activity of enterocins from different strains or sources. The variation of inhibitory spectrum among enterococcus isolates results from different enterocin genotypes among species $(14,15,16)$.

The present results revealed that there are huge differences among the E. faecium and E. faecalis strains in terms of inactivation potential. On the other hand, any correlation could not be established between the origin of strains and inhibition efficacy. Generally, antimicrobial potential of enterococci was heterogeneous and strainspecific because of its ubiquitous nature and persistence $(4,10,17)$. Furthermore, inhibitory spectrum of $E$. faecium and $E$. faecalis may change according to pathogenic bacteria strains (7)

In conclusion, the present study revealed that enterococcal isolates from food and clinical isolates have the ability to produce bacteriocinogenic substances against pathogenic bacteria. Enterocins from food and clinical sources has potential to use in food industry as 
biopreservatives against pathogens. However, the effectiveness of enterocins should be tested in the food systems and stability of enterocins should be investigated at different conditions such as $\mathrm{pH}$ and temperature. Additionally, the relationship between bacteriocin production, hemolysis, antibiotic resistance and the presence of virulence factors should be individually evaluated to determine the safety and risk factors of bacteriocins from food and clinical sources.

\section{Acknowledgements}

This work was supported by Çukurova University Scientific Research Projects Group (Project No. ZF2010YL83).

\section{Conflict of Interest}

The authors declared that there is no conflict of interest.

\section{References}

1. Achemchem F, Bueno MM, Abrini J et al (2005): Enterococcus faecium F58, a bacteriocinogenic strain naturally occurring in Jben, a soft, farm house goat's cheese made in Morocco. J Appl Microbiol, 99, 141-15.

2. Anandani JH, Khan ZH (2014): Isolation, partial purification and biochemical characterization of enterocin producing enterococci. Indian J Appl Res, 4, 18-20.

3. Aroujo TF, Ferreira LLF (2013): The genus Enterococcus as probiotic: Safety concerns. Braz Arch Biol Techn, 56, 457-466.

4. Belicová A, Mikulášová M, Krajčovič J et al (2011): Antibacterial activity and enterocin genes in enterococci isolated from Bryndza cheese. J Food Nutr Res, 50, 21-32.

5. Belguesmia Y, Choiset Y, Pr'evost $\mathbf{H}$ et al (2010): Partial purification and characterization of the mode of action of enterocin s37:a bacteriocin produced by Enterococcus faecalis 537 isolated from poultry feces. J Environ Pub Health, 986460, 1-8.

6. Cisneros YMA, Espuñes TRS, Wacher C et al (2011): Enterocins: Bacteriocins with Applications in the Food Industry. 1330-1341. In: A. Méndez-Vilas (Ed), Science Against Microbial Pathogens: Communicating Current Research and Technological Advances, Microbiology Series (No 3). Formatex, Badajoz, Spain.

7. De Vuyst L, Morenoa MRF Revets H (2003): Screening for enterocins and detection of hemolysin and vancomycin resistance in enterococci of different origins. Int $\mathrm{J}$ Food Microbiol, 84, 299-318.

8. Franz CMAP, Toit MD, Holy A et al (1997): Production of nisin-like bacteriocins by Lactococcus lactis strains isolated from vegetables. J Basic Microbiol, 37, 187-196.

9. Ghrairi T, Free J, Berjeaud JM et al (2008): Purification and characterization of bacteriocin produced by Enterococcus faecium from Tunisian Rigouta Cheese. Food Control, 19, 162-169.

10. Gómez NC, Abriouel H, Grande MJ et al (2012): Effect of enterocin AS-8 in combination with biocides on planktonic and sessile Listeria monocytogenes. Food Microbiol, 30, 51-58.

11. Isleroglu H, Yildirim Z, Tokatli M (2012): Partial characterization of enterocin KP produced by Enterococcus faecalis KP, a cheese isolate. Int J Dairy Techn, 65, 90-97.

12. Javed A, Masud T, Ain Q et al (2011): Enterocins of Enterococcus faecium, emerging natural food preservatives. Ann Microbiol, 61, 699-708.

13. Javed I, Ali MI, Ahmed B, et al (2011): Optimization and partial purification of bacteriocins from Enterococcus spp. indigenous to Pakistan. Food Biotechn, 25, 130-139.

14. Khalkhali S, Mojgani N (2017): Bacteriocinogenic potential and virulence traits of Enterococcus faecium and E. faecalis isolated from human milk. Iranian J Microbiol, 9, 224-233.

15. Marekova M, Laukova A, De Vuyst L, et al (2003): Partial characterization of bacteriocins produced by environmental strain Enterococcus faecium EK13. J Appl Microbiol, 94, 523-530.

16. Moreno MRF, Callewaert R, Devreese B, et al (2003): Isolation and biochemical characterization of enterocins produced by enterococci from different sources. J Applied Microbiol, 94, 214-229.

17. Nascimento MS, Moreno I, Kuaye AY (2010): Antimicrobial activity of Enterococcus faecium fair-E 198 against Gram-Positive pathogens. Braz J Microbiol, 41, 7481.

18. Ogaki MB, Rocha KR, Terra MR, et al (2016): Screening of the enterocin-encoding genes and antimicrobial activity in Enterococcus species. J Microbiol Biotechn., 26, 10261034.

19. Özdemir GB, Oryaşın E, Bıyık HH, et al (2011): Phenotypic and genotypic characterization of bacteriocins in enterococcal isolates of different sources. Indian $\mathbf{J}$ Microbiol, 51, 182-187.

20. Perumal V, Repally A, Dasari A, et al (2016): Partial purification and characterization of bacteriocin produced by Enterococcus faecalis DU10 and its probiotic attributes. Prep Biochem Biotech, 46, 686-694.

21. Savadago A, Ouattara CAT, Bassole IHN (2004): Antimicrobial activities of lactic acid bacteria strains isolated from Burkinofaso fermented milk. Pak J Nutr, 3, 174-179.

22. Sfaxi IH, Ghaish SE, Ahmadova A, et al (2011): Antimicrobial activity and safety of use of Enterococcus faecium PC4.1 isolated from Mongol yogurt. Food Control, 22, 2020-2027.

23. Sivakumar N, Saif R, Saif AB (2010): Partial characterization of bacteriocins produced by Lactobacillus acidophilus and Pediococcus acidilactici. Braz Arch Biol Techn, 53, 1177-1184.

24. Sparo MD, Castro MS, Andino PJ, et al (2006): Partial characterization of enterocin MR99 from a corn silage isolate of Enterococcus faecalis. J Appl Microbiol, 100, 123-134.

25. Theppangna W, Murase T, Tokumaru N, et al (2007): Screening of the enterocin genes and antimicrobial activity against pathogenic bacteria in Enterococcus strains obtained from different origins. J Vet Med Sci, 69, 12351239. 
26. Toit MD, Franz CMAP, Dicks LMT, et al (2000): Preliminary characterization of bacteriocins produced by Enterococcus faecium and Enterococcus faecalis isolated from pig faeces. J Appl Microbiol, 88, 482-494.

27. Tulini FL., Gomes BC, Martinis ECP (2011): Partial purifcation and characterization of a bacteriocin produced by Enterococcus faecium 130 isolated from mozzarella cheese. Ciênc Tecnol Aliment, 31, 155-159.

28. Vimont A, Fernandez B, Hammami R, et al (2017): Bacteriocin-producing Enterococcus faecium lcw44: a high potential probiotic candidate from raw camel milk. Front Microbiol, 8, 1-8.

29. Vijayakumar PP, Muriana PM (2017): Inhibition of Listeria monocytogenes on ready-to-eat meats using bacteriocin mixtures based on mode-of-action. Foods, 6, 113.

30. Yildirim Z, İlk Y, Yildirim M, et al (2014): Inhibitory effect of enterocin KP in combination with sublethal factors on Escherichia coli O157:H7 or Salmonella Typhimurium in BHI broth and UHT milk. Turk J Biol, 38, 412-419. 